\title{
FOTOGRAFIA E MELANCOLIA: AL BERTO
}

(E BARTHES)

\section{Gustavo Cerqueira}

Guimarães*

RESUMO: Este estudo visa a articulação entre fotografia e melancolia presentes na obra do escritor lusitano AI Berto (1948-1997). Essa relação se intensifica e se ilumina com base em Giorgio Essa relação se intensifica e se ilumina com base em Giorgio Agamben e Sigmund Freud. No caso da articulação com o psicanalista, a abordagem é menos associada à afecção melancólica - suas derivações nosográficas e psicologizantes -, do que àquela feita pela via estética, mais explícita no pensador italiano. As relações mais estreitas entre fotografia e melancolia se estabeSontag, autores que dedicaram livros e estudos ao assunto.

PALAVRAS-CHAVE: Al Berto; fotografia; melancolia; psicanálise: Roland Barthes.

* gustavocguimaraes@hotmail.com

Doutor em Teoria da Literatura e Literatura Comparada e mestre em

RÉSUMÉ: Cet article vise à mettre de l'avant l'articulation entre la photographie et la mélancolie dans l'œuvre de l'écrivain lusitanien Al Berto (1948 au 1997). Cette relation s'intensifie et s'illumine à partir des études de Giorgio Agamben et Sigmund Freud. Par rapport au psychanalyste, I'approche est moins associé à l'affection mélancolique - ses dérivations nosographique et psychologisante -, que celle réalisée par la voie esthétique. Cette voie esthétique est plus explicite chez le penseur italien. De même, des rapports plus étroits entre la photographie et la mélancolie sont relevés par les réfléxions de Roland Barthes et Susan Sontag qui ont écrit des ouvrages sur ce sujet.

MOTS-CLÉ: Al Berto; photographie; mélancolie; psychanalyse; Roland Barthes. 
A pintura simula a vida, e a fotografia não simula nada. Mata. É um tiro, em que tudo para. A pintura tem uma imobilidade na mobilidade, por seu lado a fotografia é a arte que mais tem relação com a morte É a descida aos infernos. Mas tanto a pintura como a fotoa morte. É a descida aos infernos. Mas tanto a pintura como a fotografia fertilizam a ninha escrita, porque são as referencias que tenho, pois não há razão para não transpor para escrita tudo o que a pode enriquecer e transformar. $O$ autor funciona como filtro. E é tão vivo!

$A$ vida não são detalhes significativos, instantes reveladores, fixos para sempre. As fotos sim

Susan Sontag

Durante toda a sua trajetória artística, entre 1967 e 1997, Al Berto manteve uma intensa produção poética na mais ampla possibilidade que esse vocábulo possa carregar, associando à sua obra a veiculação da própria imagem junto ao público e colhendo os benefícios e malefícios de se expor profusamente, ao contrário de alguns autores de nossa língua portuguesa, Herberto Helder e Dalton Trevisan, por exemplo, que quase sempre se negaram a serem capturados pelas câmeras ou pela mídia, de maneira mais ampla.

Al Berto posou para as fotografias das capas de seus livros, concedeu entrevistas à mídia impressa e televisiva dos idos finais do século $\mathrm{XX}$, recitou por muitas vezes poemas em público, além de possuir uma lírica que, segundo o crítico português Fernando Pinto do Amaral, "pretende funcionar como testemunho de um sujeito, de um eu que não teme

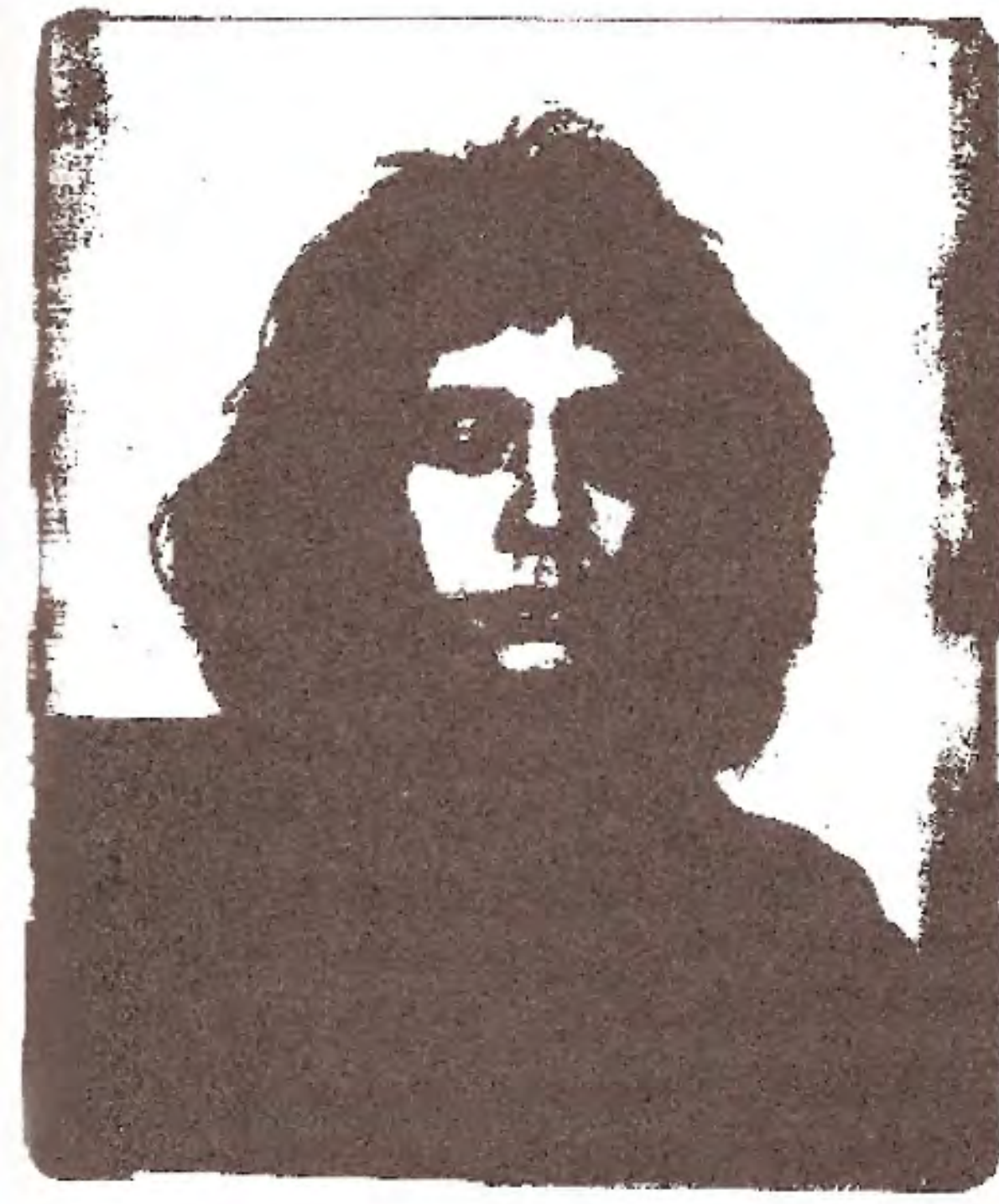

arrastar toda a carga dos seus afetos para as páginas que escreve. (...) O recorte inegavelmente narcísico desta obra poderá ter afastado alguns leitores, (...) [pois exibe] ostensivamente 
1. AMARAL. Al Berto: um lirismo do excesso e da melancolia, p. 119.

2. A primeira edição de Projets 69 foi publicada pela Montfaucon Research Center, uma associaça internacional de artistas visuais. atuantes até hoje em sua maioria fundada em $1969 \mathrm{em}$ Bruxelas fundada em 1969 em Bruxe (Franca, 1923-2006): Jölle d (França, 1923-2006); Joëlle de la Casinière (Marrocos, 1944); Berto (Portugal, 1946-1997); Olimpia Hruska (Itália, 1948); Jimpia Hruska (lália, 1948); músico, compon (França, 1950), partir de 1973. e, Sophie Podo a (Bélgica, 1953-1974), poeta (Bélgica, 1953atista grática. É nitha e intensa artísticos entre os membros desicos mare irrevere pelo contexto de ever fortes res anos sessenta e por fortes ressonâncias beatniks e, indiretamente, do pensamento deleuzeano e da semiologia barthesiana, bastante vigorosos à época. Para maior aprofundamento sobre os primeiros trabalhos de Al Berto, cf.: GUIMARAES. Al Berto, poeta editor: as margens da poesia. Estudos Linguisticos e Literários, UFBA, 2015, p. 1-18. a personalidade do poeta". ${ }^{1}$ Desde seu primeiro livro, publicado marginalmente, em Bruxelas, em 1969 (durante seu exílio por causa da ditadura salazarista), até o último, publicado pela renomada editora Assírio \& Alvim, em Lisboa, em 1997, Al Berto nunca deixou de se autorretratar. Já em sua obra de estreia, Projectos 69, o artista em várias páginas oferece ao leitor o seu rosto, sugerindo aproximações entre o sujeito que se enuncia e o autor. Os traços dessa estética são notadamente pops bem típicos do final daqueles anos, nos quais os limites entre o público e o privado ou o corpo e a arte (vida e obra) são de difícil distinção ou sequer podem ser ponderados pela categoria de limite. ${ }^{2}$

Em Al Berto percebe-se certo culto à individualidade, o que é constatado pela exacerbação em seus textos do pronome na primeira pessoa do singular - eu -, reforçando ainda mais o caráter narcisista de sua obra. Ao mesmo tempo em que essa postura distancia leitores, também os agrega de modo a tornar o autor de $O$ medo um poeta contemporâneo cultuado por certa juventude portuguesa. Os textos de Al Berto, ao lado de toda a sua expressão por imagens, são um bom exercício das possibilidades de se ler uma obra. Especificamente quando nos defrontamos com a relação que ele propõe entre a literatura e a fotografia, tanto por meio de seu emprego visual, que veremos mais adiante, como pelo escritural, que pode ser encontrado de duas formas. $\mathrm{Na}$ primeira, o texto está ligado ao gesto de fotografar, reforçando o tempo presente, como no poema "4. Leica" da série "Paulo Nozolino/4 visões":

(...) a ponta do feltro risca a pálpebra molhada de tinta as palavras surgem confusas... click!

a intensidade das luzes e por trás delas o olhar na penumbra rente ao chão aproximas-te do vidro focas disparas... o ruído da leica acorda-me para o silêncio povoado desta sala vazia. ${ }^{3}$

Já na segunda, está ligado ao tempo pretérito e à temática da memória, encontrados incontáveis vezes em seus poemas, como neste, sob o sugestivo título "1. Cabeça de pano", igualmente da série "Paulo Nozolino/4 visões":

por vezes a memória doutros dias chega-me de imagens fixas mas se a vida germinasse dalgum cristal de prata oculto nesta cabeça esculpida em pano erguendo-se sob o peso duma lua artificial... abandonaria o riso e a tristeza do corpo... partiria à procura

do segredo eterno das pirâmides ou dessa revelação ainda em suspensão no revelador dos nocturnos laboratórios 
4. AL BERTO. $O$ medo, p. 317.

5. AL BERTO. $O$ medo, p. 226. no zênite da noite levantar-se-ia o terno dedo incendiando a leveza do papel mergulhado no fixador imobilizaria o desejo

e todas as imagens se tornariam apenas resíduos visões ainda longínquas dalguma catástrofe... os rostos que na penumbra partilharam connosco a vida e depois se ocultaram. ${ }^{4}$

No entanto, tratar o tema da fotografia na literatura por variadas vezes e de diferentes maneiras por si só, e especialmente em Al Berto, já implicaria na imbricação dos tempos presente e pretérito, pois a própria fotografia, ao seu ver, já garante esse estatuto:

com fotografias consolo a saudade do rapaz que fui, embora saiba que há muito se apagaram os sorrisos de teu rosto. envelhecemos separados, o $e u$ das fotografias e o $e u$ daquele que neste momento escreve. envelhecemos irremediavelmente, tenho pena, mas é tarde e estou cansado para as alegrias dum reencontro. não acredito na reconciliação, ainda menos no regresso ao sorriso que tenho nas fotografias. não estou aqui nunca estive nelas. quase nada sei de mim. ${ }^{5}$

Ou, ainda, à maneira sugerida por Roland Barthes, em sua obra cujas primeiras páginas trazem aproximadamente quarenta fotografias do autor e de seus familiares (e suas casas) em diferentes momentos da vida: "a imageria age como um médium e me põe em relação com o 'isto' de meu corpo; ela suscita em mim uma espécie de sonho obtuso, cujas unidades são dentes, cabelos, um nariz, uma magreza, pernas com meias compridas, que não me pertencem, sem no entanto, pertencer a mais ninguém". ${ }^{6}$ Essa maneira de abordar as fotografias traz uma nova visada para o campo das reflexões sobre a representação, pois abala certa categorização da identidade cuja unidade seria fechada, coincidindo sempre o "eu" do presente com o "eu" retratado. Estampadas em seus livros ou referidas em palavras, as fotografias integram a estética desses autores, edificando-se como uma chave potente e até mesmo desconcertante de leitura.

Responsável pela maioria das fotografias de $\mathrm{Al}$ Berto em seus livros, o fotógrafo Paulo Nozolino é um destacado e influente artista contemporâneo português; ${ }^{7}$ o diálogo entre eles se dá em cinco ocasiões: O último habitante (1983), Salsugem (1984), A seguir o deserto (1984), O medo (1987) e Horto do incêndio (1997). A respeito desta última obra, Eduardo Prado Coelho nos propõe começar a lê-la pela encenação fotográfica de Al Berto impressa na capa. ${ }^{8}$

Talvez se possa começar por aquilo que fica à volta do texto e que o protege, envolve e ampara (tecnicamente, poder-se-á falar de paratexto). (...) As capas dos livros de Al Berto (...) fazem parte, numa colaboração indireta mas decisiva, do pró-
6. BARTHES. Roland Barthes por Roland Barthes, p. 7.

7. Paulo Nozolino é um dos mais premiados fotógrafos lusitanos. Nasceu em 1955, em Lisboa. Vive e trabalha entre Lisboa e Paris. Expõe e publica regularmente desde 1980. Recebeu alguns prêmios e bolsas internacionais, dentre eles: Prêmio Kodak (Portugal, 1988), Prix Fondation Leica (França, 1989), Bolsa Villa Médicis Hors-les-Murs (Paris, 1994), Grand Prix de la Ville de Vevey (Suíça, 1995), Deutscher Fotobuchpreis (Stuttgart, 2005) e Prémio Autores - Artes Visuais, Sociedade Portuguesa de Autores (Lisboa, 2013). A su obra espelha o nomadismo, expresso igualmente em Al Berto.

8. A imagem da capa de Horto de incêndio foi tratada em ensaio de minha autoria. Cf.: GUIMARÃES. Al Berto, um corpo incendiado. In: FORNACIARI (org.). Corpo em contexto, 2014, p. 64-77.
EM TESE

BELO HORIZONTE

v. 21

N. 2

MAIO-AGO. 2015

GUIMARÃES. Fotografia e melancolia: Al Berto (e Barthes)

p. $90-112$ 
9. COELHO apud ANGHEL. $A$ metafísica do Medo, p. 91. prio texto. Elas servem para encenar, num narcisismo que se defende através de diversas camadas ou véus de ironia, o lugar da subjetividade em que o livro se desenrola, o seu coração arfante, opaco e exposto: "vês no espelho/ o homem cuja solidão atravessou quase cinco décadas e/ está agora ali a olhar-te”. E, por último, a imagem coloca a pergunta que o texto vai repetir: "que horas serão dentro do meu corpo?". 9

Retenham-se desta passagem os seguintes temas: a indagação do sujeito acerca do tempo, a fotografia, o narcisismo, a ironia, o coração arfante; para em conjunto serem articulados a um só tema crucial neste estudo: fotografia e melancolia em Al Berto.

Para o crítico português João Barrento, no artigo "O astro baço: a poesia portuguesa sob o signo de Saturno” (1994), os poetas portugueses dos últimos cem anos são regidos pelo signo da melancolia, estão sob o signo de Saturno. Porém, o autor empenha-se mais em analisar os poetas a partir da “geração de 1970”, porque neles o

tom plasma-se num pathos com cambiantes diversamente melancólicos: corrosivo já em Joaquim Magalhães, displicente e autoirônico em Vasco Graça Moura, narcisista em Al Berto, minimal e ciciado em Helder Moura Pereira. (...) Mas em todos está presente uma consciência vígil do tempo da escrita, deste nosso fim de época marcado por sinais de uma negati- vidade que encontra o seu lugar nesta poesia em termos de figuras ambíguas da ausência, da ruína e da morte. ${ }^{10}$

Essa articulação da melancolia com a literatura portuguesa contemporânea já havia sido feita por Fernando Pinto do Amaral em seu livro O mosaico fluido (1991), inclusive usado como referência por Barrento, um dos tradutores de Walter Benjamin. No capítulo intitulado "Al Berto: um lirismo do excesso e da melancolia", Amaral dedica sua análise somente ao autor nascido em Sines, uma pequena cidade alentejana de pescadores, afirmando contundentemente que seu universo pode ser considerado como

um dos mais melancólicos da nossa poesia recente. Seu tem sido o culto dessa difícil arte da melancolia, essa sensação psico-afectiva herdeira da acedia medieval e em que se conjugam, saturnianamente e numa indefinível mistura, o torpor, a nostalgia e o tédio. Num estudo clássico, Klibanski, Panofsky, Saxl definem a melancolia como "um sentimento de duas faces, que de si mesmo perpetuamente se alimenta e pelo qual a alma frui a sua própria solidão, mas sofrendo mais intensamente, através de tal experiência, o sentimento dessa solidão, uma espécie de alegria no sofrimento. [...] Este humor melancólico moderno corresponde essencialmente ao exacerbar da consciência de si, já que o eu é o eixo entorno do qual gira a esfera da alegria e da tristeza" (Klibanski et alii, 1989, p. 374-5). ${ }^{11}$ 
Esse componente agônico igualmente se apresenta nas encenações fotográficas de $\mathrm{Al} \mathrm{Berto,} \mathrm{um} \mathrm{dos} \mathrm{autores} \mathrm{que}$ sem dúvida alguma mais empregou o universo da fotografia à literatura. Por meio delas e de seus textos, como veremos, apresentam-se alguns traços relevantes para associá-los ao sujeito melancólico. Para tanto, antes, como bem sugerido por Fernando Pinto do Amaral, realiza-se uma breve digressão ao tema da melancolia (para demonstrar certa fixidez ao longo da história ocidental) a partir de Giorgio Agamben e Sigmund Freud para melhor nos aproximarmos da estética fin de siècle al-bertiana.

\section{MELANCOLIA: O OBJETO PERDIDO}

(...) ao fim de algum tempo, o que estava fora de mim passou a ser igual ao que estava dentro de mim - Luz e Sombra.

E foi com Luz e Sombra que iniciei, no papel, a construção da minha biografia.

Al Berto

A afecção denominada melancolia está presente entre nós desde a origem da cultura ocidental, sendo objeto de reflexão da medicina, da filosofia e das artes. A partir dos estudos de alguns dos teóricos de referência sobre o assunto, Historia del tratamiento de la melancolía desde los Orígenes hasta 1900 (1962), de Jean Starobinski, e Saturno y la melancolía: estudios de historia de la filosofía de la naturaleza, la religión y el arte (1964), de Raymond Klibansky, Erwin Panofsky e Fritz Saxl, convencionou-se dividir a história da melancolia em três períodos: Antiguidade Clássica, Idade Média e Modernidade. ${ }^{12}$ Veja-se um breve percurso histórico, com enfoque especial na psicanálise.

$\mathrm{Na}$ Grécia Antiga, encontra-se o clássico texto de Aristóteles sobre a temática saturnina, $O$ homem de gênio e a melancolia, no qual o filósofo a trata pelo prisma de uma afecção que também é benéfica, pois são os homens de exceção, os gênios, que são tomados por males originados da bile negra - melas (negra) e chole (bile). Desde então, está instaurada uma das atribuições mais marcantes da melancolia: o seu caráter paradoxal, ressaltado por Aristóteles da seguinte forma: "a potência da bile negra é inconstante, inconstantes são os melancólicos. E, com efeito, a bile negra é muito fria e muito quente". ${ }^{13} \mathrm{O}$ filósofo grego é também ponto crucial das instigantes reflexões de Giorgio Agamben no livro Estâncias, dedicado ao tema da melancolia.

$\mathrm{Na}$ abertura do primeiro capítulo deste livro, intitulado "O demônio meridiano", é contextualizada a melancolia, ou melhor, a acídia na Idade Média, informando-nos que, nessa época, um flagelo pior que a peste se manifestou sobre a população europeia. Os padres tentavam intervir contra os perigos desse "demônio meridiano" que assaltava suas
12. Cf. LAGES. Walter Benjamin: tradução e melancolia, p. 31-38. Para um maior aprofundamento do tema, sobretudo a respeito do livro Saturno e melancolia, veja o artigo "Sob o signo da iconologia: uma exploração do livro Saturno e a melancolia, de R. Klibansky, E. Panofsky e F. Saxl", de Sérgio Alcides. In: Topo - Revista de História, 2001, p.

$$
\text { 131-173. }
$$

13. ARISTOTELES. O homem de gênio e a melancolia, p. 105. 
vítimas por volta do meio-dia. Segundo Agamben, para São Tomás de Aquino, uma distinta voz do catolicismo medieval, "o que preocupa o acidioso não é, pois, a consciência de um mal, e sim, pelo contrário, o fato de ter em conta o mais elevado dos bens: acídia é o vertiginoso e assustado retrair-se frente ao compromisso da estação do homem diante de Deus". ${ }^{14}$ Por esse motivo, é um mal mortal, porque se afasta do bem divino: "trata-se da perversão de uma vontade que quer o objeto, mas não quer o caminho que a ele conduz e ao mesmo tempo deseja e obstrui a estrada ao próprio desejo". ${ }^{15}$ Daí, novamente, o caráter paradoxal da acídia, que Agamben reforça ao finalizar o capítulo:

a ambígua polaridade negativa da acídia se torna o fermento dialético capaz de transformar a privação em inacessível, a acídia não constitui apenas uma fuga de..., mas também uma fuga para..., que se comunica com seu objeto sob a forma da negação e da carência. Assim como acontece com as figuras ilusórias que podem ser interpretadas ora de um, ora de outro modo, assim também cada traço seu desenha, na sua concavidade, a plenitude daquilo de que se afasta, enquanto cada gesto realizado por ela na sua fuga testifica a manutenção do vínculo que a liga a ele.

Ao mesmo tempo em que a sua tortuosa intenção abre espaço à epifania do inapreensível, o acidioso dá testemunho da obscura sabedoria segundo a qual só a quem já não tem esperança foi dada a esperança, e só a quem, de qualquer maneira, não poderá alcançá-las foram dadas metas a alcançar. Tão dialética é a natureza do seu "demônio meridiano": assim como se pode dizer da doença mortal, que traz em si a possibilidade da própria cura, também daquela se pode afirmar que a maior desgraça é nunca tê-la tido. ${ }^{16}$

6. AGAMBEN. Estâncias, p. 32 .

Segundo Agamben, sob muitos aspectos, essa descrição patrística não desapareceu na Modernidade, pois é sob o regime atrabiliário que se pautará a literatura moderna, tendo em Baudelaire um expoente, pois toda a sua poesia pode ser entendida "como uma luta mortal com a acídia e, ao mesmo tempo, como uma tentativa de invertê-la em algo positivo. Convém observar que o dandy, que representa, segundo Baudelaire, o tipo perfeito do poeta, pode ser considerado, em certo sentido, como reencarnação do acidioso"; ${ }^{17}$ embora a acídia tenha se esvaziado de seu significado patrístico em detrimento da "ética capitalista do trabalho". No entanto, como sugere o pensador, "se examinarmos a interpretação que os doutores da Igreja dão à essência da acídia, veremos que ela não é posta sob o signo da preguiça, mas sim sob o da angustiada tristeza e do desespero" ${ }^{18}$

Além da literatura moderna, que tem em Baudelaire um exemplo da temática atrabiliária no século XIX, ainda sob o signo da Modernidade encontram-se a psiquiatria e a psicanálise freudiana como formas discursivas de considerável influência para o pensamento do século XX, devido ao seu influxo na cultura ocidental. Conforme Freud, a melancolia para a
17. AGAMBEN. Estâncias, p. 24

18. AGAMBEN. Estâncias, p. 27 
19. Cf. FREUD. Luto e Melancolia, p. 271-291.

20. FREUD. Luto e Melancolia, p. 277.

21. FREUD. Luto e Melancolia, p. 279 psiquiatria possui várias formas clínicas, tratando-se antes de uma afecção somática do que psicogênica. Já para a psicanálise a melancolia será abordada como um caso de natureza psicológica indiscutível. ${ }^{19}$ Em "Luto e melancolia", o autor pretende fazer uma analogia entre a melancolia e o "afeto normal do luto", já que o quadro geral dessas duas afecções é bem parecido. Em ambos os casos há a perda do objeto, sendo que naquela a perda é ideal: "sabe-se quem perdeu, mas não o que perdeu". ${ }^{20}$ Essa característica tem implicações na estrutura egoica, pois, na melancolia, o ego se torna pobre e vazio, acarretando diminuição da autoestima, inibição da libido, desânimo, perda da capacidade de amar, autorrecriminação e autoenvilecimento, culminando em uma expectativa delirante de punição, enquanto que no luto é o mundo que se torna pobre e vazio, não o ego. Freud acredita que a autoacusação e a autocrítica, encontradas nos melancólicos, os dispõem a uma visão mais penetrante da verdade, se comparados a outras pessoas que não são melancólicas. Tal posição é justificada pelo fato de que o melancólico parece conhecer mais sobre si mesmo, visto que "ficamos imaginando, tão-somente, por que um homem precisa adoecer para ter acesso a uma verdade dessa espécie”. ${ }^{21}$ Tal postulação vai ao encontro do que é proposto por Aristóteles em $O$ homem de gênio e a melancolia. Entretanto, como atesta Freud, é difícil ver até que ponto há uma correspondência entre o grau de autodegradação e sua real justificação. A psicanálise ainda não conseguiu explicar como o ego do melancólico pode consentir em sua própria destruição. O fato é que os melancólicos chegam a usar o sadismo e a autopunição como vingança, para torturar o objeto amado por intermédio da sua doença, encontrando-se, em boa parte dos casos, esse objeto amado perto do melancólico. Freud ainda postula que não é fácil reconstruir o processo da melancolia, porque

existem, num dado momento, uma escolha objetal, uma ligação da libido a uma pessoa particular; então, devido a uma real desconsideração ou desapontamento proveniente da pessoa amada, a relação objetal foi destroçada. O resultado não fo o normal - uma retirada da libido desse objeto e um deslocamento da mesma para um novo -, mas algo diferente, para cuja ocorrência várias condições parecem ser necessárias. A catexia objetal provou ter pouco poder de resistência e foi liquidada. Mas a libido livre não foi deslocada para outro objeto; foi retirada para o ego. Ali, contudo, não foi empregada de maneira não especificada, mas serviu para estabelecer uma identificação do ego com o objeto abandonado. Assim a sombra do objeto caiu sobre o ego, e este pôde, daí por diante, ser julgado por um agente especial, como se fosse um objeto abandonado. Dessa forma, uma perda objetal se transformou numa perda do ego, e o conflito entre o ego e a pessoa amada, numa separação entre a atividade crítica do ego e o ego enquanto alterado pela identificação. ${ }^{22}$

Por vezes, as mesmas condições do luto provocam a melancolia. Porém, "a melancolia está de alguma forma

\begin{tabular}{|c|c|c|c|c|c|c|}
\hline EM TESE & BELO HORIZONTE & v. 21 & N. 2 & MAIOAGO. 2015 & GUIMARÃES. Fotografia e melancolia: Al Berto (e Barthes) & P. 90-112 \\
\hline
\end{tabular}


23. FREUD. Luto e Melancolia, p. 278.

24. FREUD. Luto e Melancolia p. $289-290$

\section{Cf. FREUD. Luto e Melancolia,} p. 284. relacionada a uma perda objetal retirada da consciência, em contraposição ao luto, no qual nada existe de inconsciente a respeito da perda". ${ }^{23}$ Tanto no luto como na melancolia há a retirada do investimento libidinal e o objeto de amor não mais existe. No entanto, a afecção melancólica é ambivalente, pertencente, por natureza, ao recalcado.

As causas excitantes da melancolia têm uma amplitude muito maior do que as do luto, que é, na maioria das vezes, ocasionado por uma perda real do objeto, por sua morte. Na melancolia, em consequência, travam-se inúmeras lutas isoladas em torno do objeto, nas quais o ódio e o amor se digladiam; um procura separar a libido do objeto, o outro defender essa posição da libido contra o assédio. A localização dessas lutas isoladas só pode ser atribuída ao sistema Ics. [inconsciente], região dos traços da memória de coisas. ${ }^{24}$

Essa ambivalência se deve ao fato de o melancólico possuir, em relação ao objeto amado, sentimentos de amor e ódio. O ódio pode se intensificar, se o melancólico se refugiar na identificação narcisista e colocá-lo em ação contra o objeto, degradando-o. ${ }^{25}$ Para Freud, esses sentimentos ambivalentes se dão no nível do inconsciente, como bem postulado acima. A seguinte formulação de Giorgio Agamben talvez se faça bastante pertinente no que tange à questão dessa ambivalência em Freud: na melancolia, o objeto não é nem apropriado nem perdido, mas as duas coisas acontecem ao mesmo tempo. E assim como o fetiche é, ao mesmo tempo, o sinal de algo e da sua ausência, e deve a tal contradição o próprio estatuto fantasmático, assim, o objeto da intenção melancólica é, contemporaneamente, real e irreal, incorporado e perdido, afirmado e negado. ${ }^{26}$
EM TESE
BELO HORIZONTE
v. 21
N. 2
MAIO-AGO. 2015
GUIMARÃES. Fotografiia e melancolia: Al Berto (e Barthes)
P. 90-112

da libido melancólica não visa senão tornar possível uma apropriação em uma situação em que posse alguma é, realmente, possível. Sob essa perspectiva, a melancolia não seria tanto a reação regressiva diante da perda do objeto de amor, quanto a capacidade fantasmática de fazer aparecer como perdido um objeto inapreensível. Se a libido se comporta como se tivesse acontecido uma perda, embora nada tenha sido de fato perdido, isso acontece porque ela encena uma simulação em cujo âmbito o que não podia ser perdido, porque nunca havia sido possuído, parece como perdido, e aquilo que não podia ser possuído porque, talvez, nunca tenha sido real, pode ser apropriado enquanto objeto perdido. Nesta altura, torna-se compreensível a ambição específica do am- 
bíguo projeto melancólico, que a analogia com o mecanismo exemplar do luto havia desfigurado parcialmente e tornado irreconhecível, e que justamente a antiga teoria humoral identificava na vontade de transformar em objeto de abraço o que teria podido ser apenas objeto de contemplação. Cobrindo o seu objeto com os enfeites fúnebres do luto, a melancolia lhes confere a fantasmagórica realidade do perdido. ${ }^{27}$

Agamben, no capítulo intitulado "O fantasma de Eros", comenta que Freud não desenvolveu uma teoria orgânica do fantasma, mas deixou resquícios ao pronunciar que o melancólico não aceita a realidade tal como lhe é apresenta$\mathrm{da}$, e se esquiva do real ao criar os fantasmas do desejo que penetram na consciência e que passam a ser aceitos como uma melhor realidade. $O$ autor acrescenta que essa faculdade fantasmática já era há tempos vinculada à melancolia pela tradição antiga e que a psicanálise contemporânea resgatou essa ideia, sobretudo, a partir de Jacques Lacan, pois a gênese do amor já se apresentava como um processo fantasmático desde a lírica trovadoresca, que muito influenciou a poesia ocidental moderna:

a perda imaginária que se apodera tão obsessivamente da in tenção melancólica não tem objeto real algum, porque sua fúnebre estratégia está voltada para a impossível captação do fantasma. $\mathrm{O}$ objeto perdido não é nada mais que a aparência que o desejo cria para o próprio cortejo do fantasma, e a introjeção da libido nada mais é que uma das faces de um processo no qual aquilo que é real perde a sua realidade, a fim de que o que é irreal se torne real. ${ }^{28}$ 
Regressa e oferece-te à preguiça triste de quem continua aqui, vivo, sorvendo a espiral da sua própria ausência.

Regressa, peço-te, mesmo antes de partires. Regressa à voracidade do desejo, e à incendiada paixão dos nocturnos tigres... ${ }^{29}$

Em toda tessitura de Al Berto (carta, diário, poema, conto, romance, dramaturgia, desenho, fotografia e performance), é recorrente o traço melancólico, que se potencializa exatamente pelo jogo de contraste, próprio de sua particularidade.

Basta um rápido contacto com a sua obra para nos apercebermos da insistência com que o spleen e a Weltschmerz se erguem ao longo do seu Medo. Cercado pela solidão, praticamente fora de si próprio, o sujeito sabe entregar-se à amargura mas compensadora tirania de uma dor que só ele conhece e que, longe de ser causada por um motivo identificável, provém de uma presença-outra, inquietante e espectral, pairando sobre o sujeito como uma invisível e fatal condenação, qualquer coisa que devagar toma conta de cada pensamento ou cada gesto, o que leva à preguiça e à imobilidade.

Assim se ascende, pouco a pouco, seja a uma serenidade rara, seja, com maior frequência, ao desconforto acidioso de ficar parado e absorto, sem energia, vítima da mais insidiosa angústia. ${ }^{30}$

0. AMARAL. Al Berto: um lirismo do excesso e da melancolia, p. 125
Essa ambivalência aparece em Al Berto na relação do sujeito com a escrita, pois este se trata quase sempre de um escritor a

nomear o mundo e suas vicissitudes. A melancolia pode também ser entendida como algo associado à perda de identidade $\mathrm{e}$ de laços do sujeito com a comunidade, ou mesmo à ausência de uma ideologia a que se apegar; ou, ainda, à sua própria disposição em direção à imobilidade. Assim, a busca de sentido para a vida narrada por essa voz dá, paradoxalmente, um caráter alegremente soturno ou soturnamente alegre à obra, exaltando a relação agonística entre autor e escrita - "calou-se quando percebeu que escrever podia ser um vício feliz ou a única mentira suportável”31 - como se verá a seguir, sendo necessário recorrer a fontes teóricas mais específicas para a articulação.

\section{FOTOGRAFIA E MELANCOLIA}

\section{de mais tarde olhar nas fotografias e já não sentir pulsar no papel vida nenhuma}

\section{Al Berto}

Nas artes visuais, desde a Idade Média, a melancolia determina uma iconografia à parte. É o que constata a pesquisa de doutorado de Susana Kampff Lages, transformada no livro Walter Benjamin: tradução e melancolia, ${ }^{32}$ no qual a autora examina algumas gravuras, indicando, sobretudo, a importância de Melencolia I(1514), do renascentista alemão Albrecht Dürer. Essa análise ressalta um ponto destacado pelos estudos já mencionados, a ambivalência inerente a toda disposição melancólica,
32. Cf. LAGES. Walter Benjamin: tradução e melancolia, p. 38-52. A autora se respalda em seu estudo na obra "antológica" Saturn and Melancholy, dos autores R. Klibansky, F. Saxl \& E. Panofsky.
EM TESE
BELO HORIZONTE
v. 21
N. 2
MAIO-AGO. 2015
GUIMARÃES. Fotografia e melancolia: Al Berto (e Barthes)
P. $90-112$ 


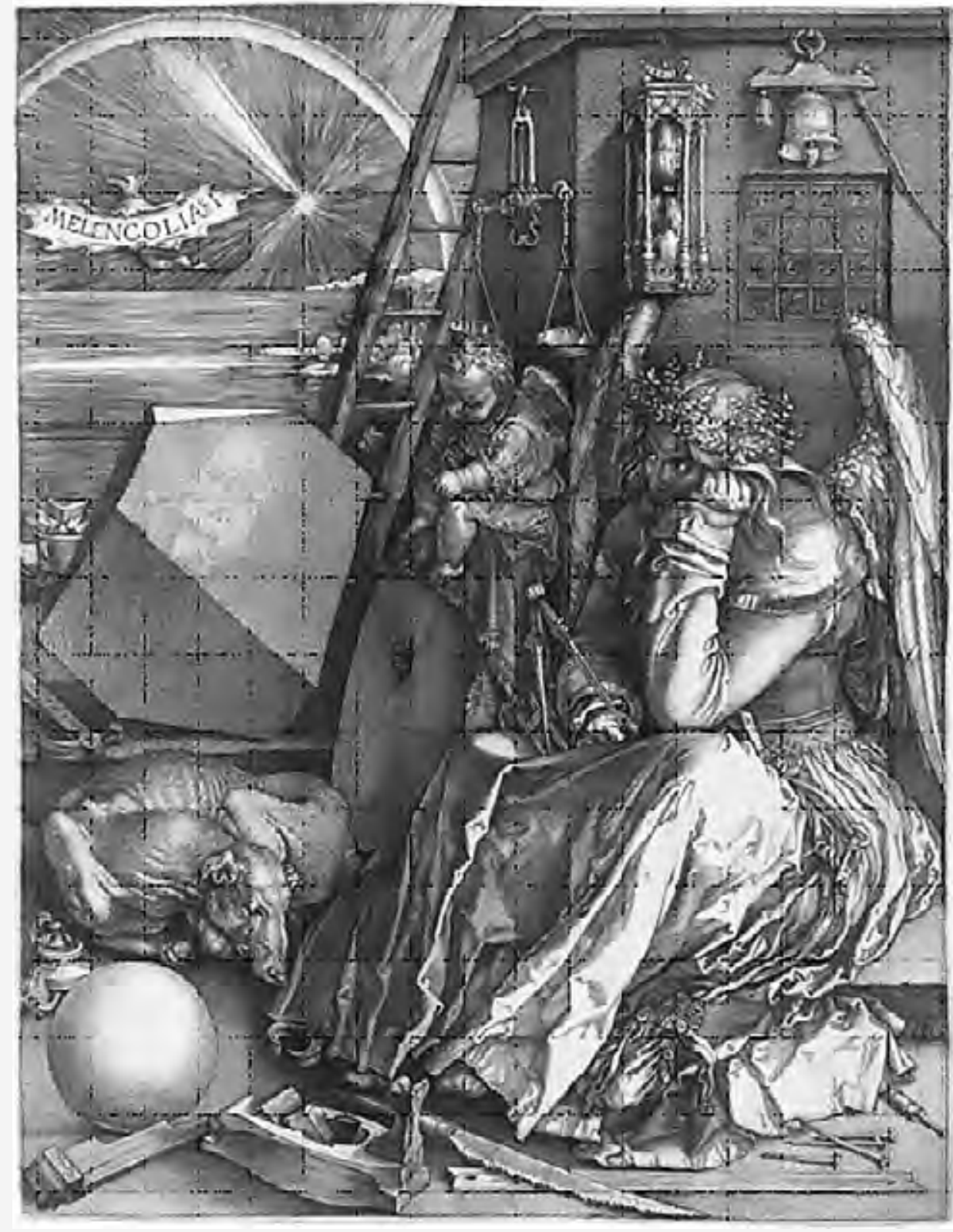

que se caracteriza pela oscilação entre posições contraditórias: alto e baixo, triste e alegre, espiritual e material, infernal e divino; e, ao nível da representação pictórica, entre claro e escuro, e caracteristicamente, na gravura, entre linha, cheia, e espaço, vazio. Entretanto, esses polos não se deixam apreender facilmente; apenas recorrendo a um terceiro elemento, à ideia de mediação, a oposição entre eles se torna produtiva, indo além de uma mera representação maniqueísta de afetos e conceitos. ${ }^{33}$

As duplicidades dessa disposição são correlatas à representação do pintor Dürer. Observe-se a imagem da referida pintura. A respeito dela, Walter Benjamin, em Origem do drama trágico alemão, ressalta também os traços ambivalentes.

O quadrado mágico que vemos desenhado num quadro por cima da cabeça da Melancolia de Dürer é o selo planetário de Júpiter, cuja influência se opõe às forças obscuras de Saturno. Ao lado deste quadro está pendurada a balança, uma alusão ao signo astrológico de Júpiter. (...) Sob esta influência jupteriana, as inspirações nefastas transformam-se em benéficas, se Saturno torna-se protector das mais sublimes pesquisas. ${ }^{34}$

Elementos igualmente contraditórios, além da característica propriamente soturna da melancolia, são encontrados em toda a poética al-bertiana; assim, em suas encenações fotográficas não seriam diferentes. Nelas, constata-se de
33. LAGES. Walter Benjamin: tradução e melancolia, p. 49

34. BENJAMIN. 3. Origem do drama trágico alemão, p. 160. 


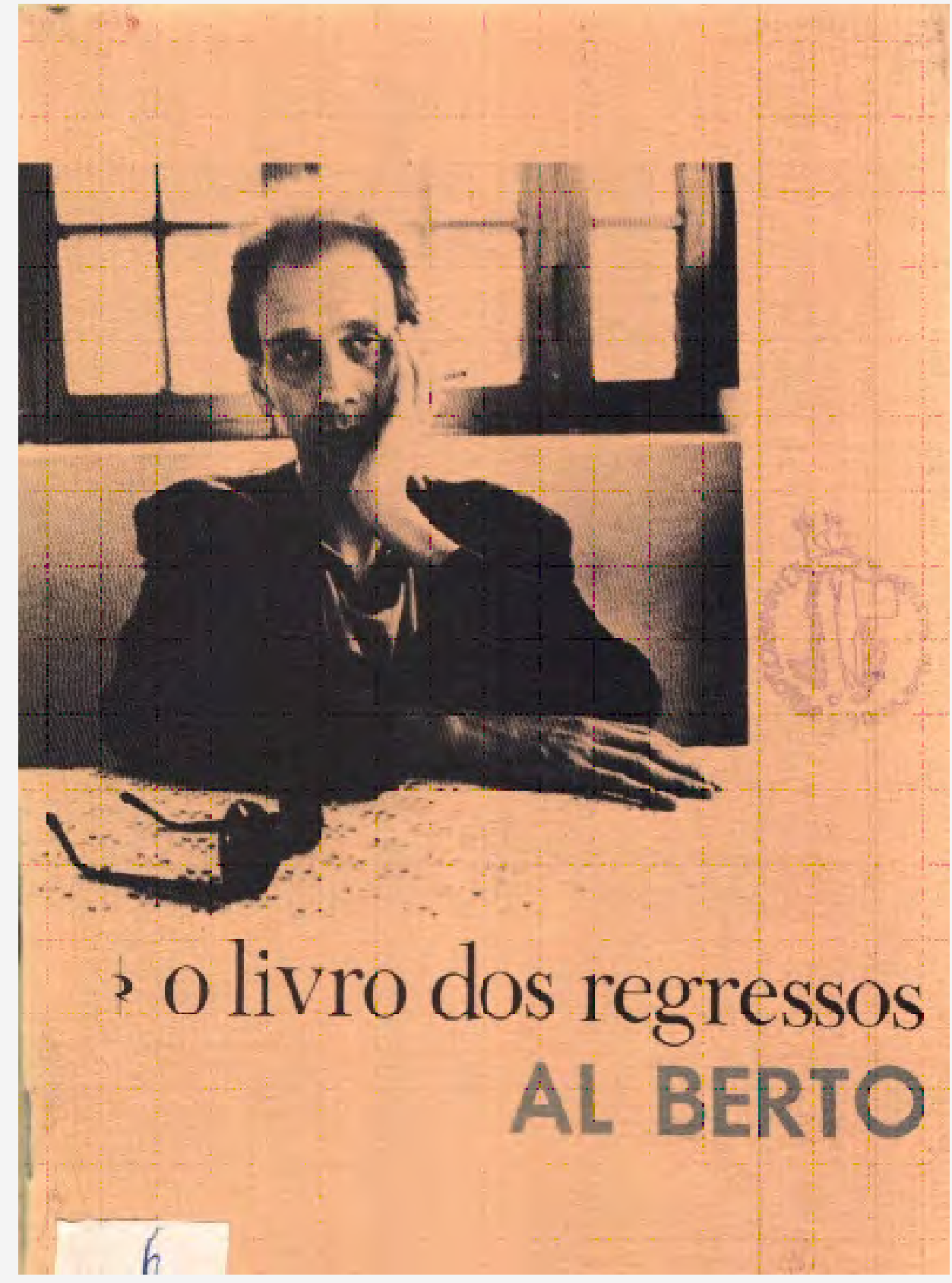

maneira mais rápida e contundente o diálogo com a tradição melancólica. A fotografia de Al Berto estampada na capa de O livro dos regressos, feita por Helder Lage, sugere aproximações com a imagem de Dürer, sobretudo por causa da pose, aparentemente despretensiosa, ao lado dos óculos escuros sobre a toalha de renda e "o cigarro quase como parte integrante da morfologia do corpo". ${ }^{35}$ Manuel de Freitas, atento a tais inclinações de Al Berto, ao analisar a imagem aponta também para os objetos que o cercam, bem como para o estado de ânimo do encenador, pois nessa foto

podemos ver uns óculos escuros depostos sobre a mesa, que metonimicamente sublinham as fundas olheiras do rosto do poeta. O rosto está apoiado pela mão esquerda, que segura um cigarro, enquanto a direita repousa sobre a mesa vazia a alguma distância dos óculos. O olhar, a preto e branco, impregna-se de uma tristeza que não hesitaremos em considerar afim dos versos que nesse livro rememoram a infância. ${ }^{36}$

A fotografia aparece em Al Berto já em $A$ procura do ven to num jardim d'agosto (1977), ainda timidamente, entre as páginas da série "Os equinócios de Tangerina". ${ }^{37} \mathrm{O}$ retrato, de Sérgio da Costa e Silva, é de uma encenação de Al Berto agachado, sem camisa, com as mãos à altura da boca, cabelos desalinhados e olhos arregalados, expressando uma fisionomia que nos faz pensar em medo. ${ }^{38}$ Segundo Eduardo
35. CASTRO. Autorretrato e construção da subjetividade na poesia de Al Berto, p. 77.

36. FREITAS. Me, myself and I, p. 60-61.

37. AL BERTO. À procura do vento num jardim d'agosto, p. 42.

38. Cf. FREITAS. Me, myself and I, p. 55. 
39. COELHO. Pensar a ausência em Al Berto, p. 13.

40. AL BERTO. O medo, p. 234.

41. AL BERTO. 0 medo, p. 370.

42. AL BERTO. O medo, p. 317.

43. AL BERTO. O medo, p. 220.
Prado Coelho, o medo em Al Berto também foi detectado e assinalado pela escritora Maria Gabriela Llansol e Joaquim Augusto, seu marido, em uma viagem que fizeram junto com Al Berto para a França. Eles "disseram que no comboio tinham falado com o Al Berto sobre o medo. O medo das capas do $\mathrm{Al}$ Berto, as suas encenações fotográficas contra o medo". ${ }^{39} \mathrm{O}$ vocábulo medo, diga-se de passagem, além de intitular a sua obra completa, é bastante reincidente em seus escritos: "medo de escrever"; ${ }^{40}$ ou, pelo contrário disso, para se dissipar de tal sensação: "escrevo para não me deixar invadir pelo medo". ${ }^{41} \mathrm{O}$ tema por vezes se apresenta de maneira irônica associado à fotografia: "vou destruir todas as imagens onde me reconheço / e passar o resto da vida assobiando ao medo". ${ }^{42} \mathrm{Ou}$, ainda, presente do modo mais costumeiro, ligado à memória, à melancolia, como no último poema, "12", do livro Trabalhos do olhar:

กล̃o

não tenho medo de morrer aqui

nem receio os cães velocíssimos de guarda

às azenhas não reveladas de teu corpo

medo da memória

sim... receio que as cabeças tristes dos galgos

aqueçam na fulguração breve dos relâmpagos

e corram repentinamente para fora do papel fotográfico

destruindo estes preciosos trabalhos do olhar. ${ }^{4}$

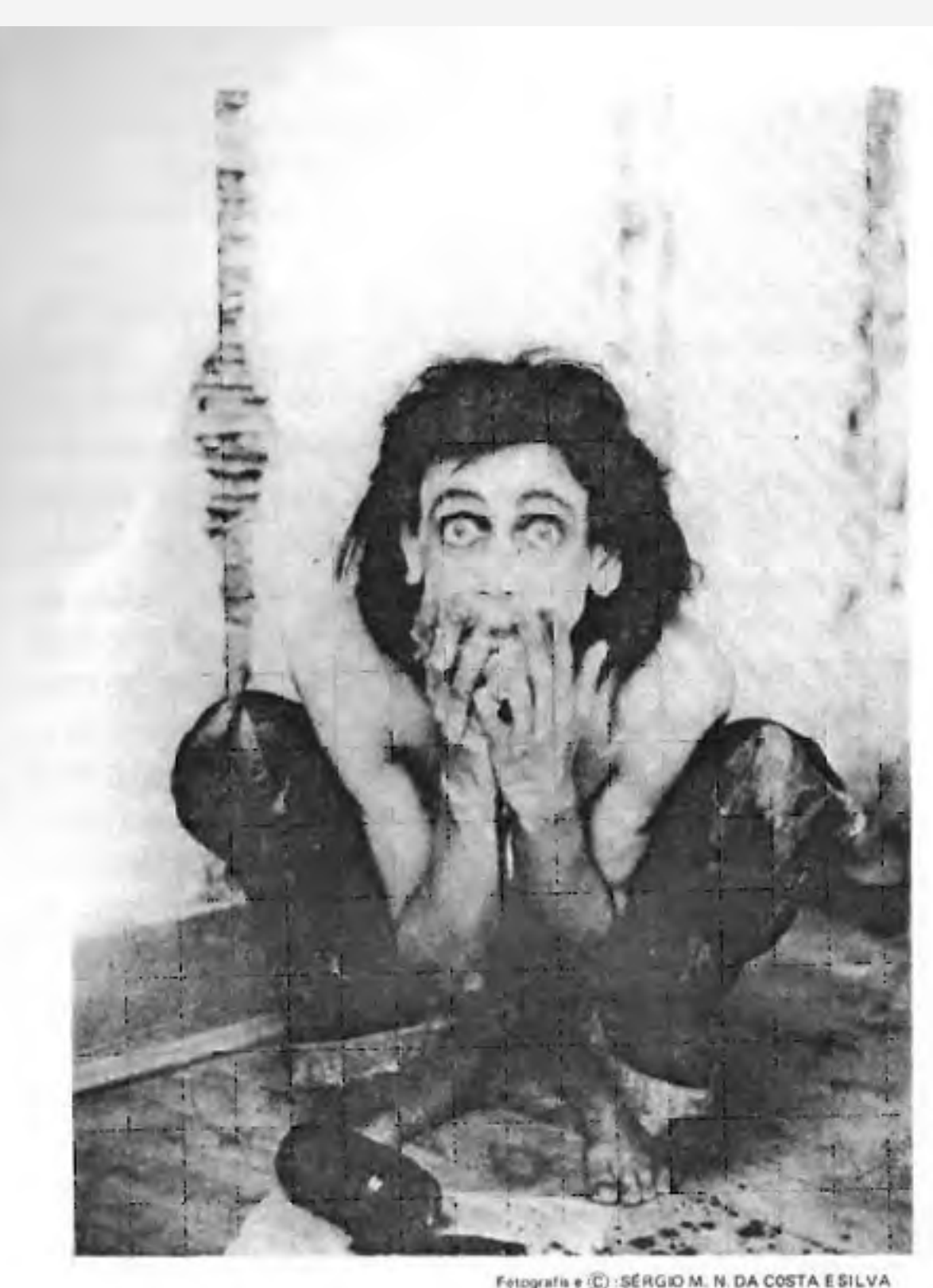

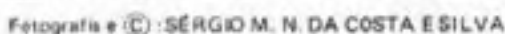


44. SONTAG. Sobre fotografia, p. 26.

45. AL BERTO. Lunário, p. 58-59.
Susan Sontag, em seu livro Sobre fotografia, adjetiva a arte fotográfica de variadas maneiras: nostálgica, melancólica, elegíaca e crepuscular, pois "toda foto testemunha a dissolução implacável do tempo", ${ }^{44}$ equivalendo a uma prova inconteste de que algo aconteceu. Assim, o retrato configura-se tanto como uma "pseudopresença" quanto como uma "prova de ausência" que as pessoas podem guardar e reencontrar outras vezes, tornando-se um fragmento do mundo capturado em miniatura. Tal postulação é recorrente em Al Berto, como se pode perceber em Lunário, na voz de Beno:

Um dia, mais tarde, olharia as poucas fotografias de Nému que guardara numa gaveta, e lembrar-se-ia certamente da noite de agonia em que resolvera queimá-las e não fora capaz de fazer. Tinha chegado à conclusão de que nenhuma delas lhe transmitia a leveza, a lentidão, a quase etérea beleza, os gestos precisos de Nému.

As fotografias (...) tinham fixado instantes agora mortos, escondidos ou desfeitos lado a lado, no chão, e acabara sempre por perder a cronologia daquele rosto. O rosto de Nému.

No entanto, encontrara em todas elas um sinal de Nému. Numa, o sorriso ou uma pálpebra, noutra, os cabelos, o sexo ou a curva do pescoço... mas nunca o retrato completo. E estes frágeis e tênues vestígios, dispersos pelas imagens, perseguiam-no como se tivessem sido graves acidentes ao longo da sua vida. ${ }^{45}$
A fotografia é associada a um certo sentimento melancólico, de perda do objeto, de algo que foi "possuído", seja pessoa ou objeto, em um tempo que não volta mais, pois ela só pode ser pretérita. E certo pensar que todos os objetos que nos cercam e todas as expressões artísticas que chegam à nossa percepção também têm sua história, mas o que se diferencia na fotografia é o fato de ela congelar o instante no qual os objetos ou pessoas estavam num determinado momento. Assim, distingue-se da filmagem, por exemplo, que a partir das imagens (fotogramas) dispostas em determinada sequência, em velocidade, configura-se em uma imagem em movimento. Poderíamos pensar na pintura, que também é uma imagem fixa, mas, no entanto, ela não tem o caráter de referencialidade que é peculiar à arte fotográfica, mesmo os retratos pictóricos mais comuns no século XIX. Então, o retrato possui um estatuto mimético particular, referindo-se à pessoa em dado momento histórico por meio de uma legenda ou outro dado de identificação qualquer, conforme atesta a portuguesa Margarida Medeiros, em seu estudo sobre fotografia e narcisismo:

a imagem parada é sempre perturbante: ela nega o movimento, a mobilidade e plasticidade do eu, a possibilidade de arrependimento e do remorso, ela nega sobretudo a afirmação da vida, porque nos transforma em coisa. Esse corte temporal apenas nos surge no retrato fotográfico, pela sua natureza instantânea e capturante. ${ }^{46}$
46. MEDEIROS. Fotografia e narcisismo, p. 50. 
48. BARTHES. A câmara clara, p. 28-29.

49. AL BERTO. $O$ medo, p. 237.
A assertiva de Medeiros está em consonância com a concepção de Roland Barthes de que a fotografia é o particular absoluto, tendo em vista que reproduz ao infinito o que nunca mais pode ser repetido existencialmente.

E aquele ou aquela que é fotografado, é o alvo, o referente, espécie de pequeno simulacro, de édolon emitido pelo objeto, que de bom grado eu chamaria de Spectrum da Fotografia, porque essa palavra mantém, através de sua raiz, uma relação com o "espetáculo" e a ele acrescenta essa coisa um pouco terrível que há em toda fotografia: o retorno do morto. ${ }^{47}$

Nessa passagem de A câmara clara, um dos livros canônicos sobre os estudos fotográficos, é enfatizado novamente um dos traços fundamentais da melancolia: o seu caráter fantasmagórico. Paira em toda fotografia, sobretudo de pessoas, essa aura saturnina, pois "quando me descubro no produto dessa operação, o que vejo é que me tornei Todo-Imagem, isto é, a Morte em pessoa" ${ }^{48} \mathrm{O}$ sujeito torna-se objeto, torna-se passivo, mortificado por meio da impressão de sua imagem no papel, como escreve $\mathrm{Al}$ Berto ao associar a imobilidade da fotografia à morte:

pernoito neste corpo magro espero a catástrofe

basta manter-me imóvel e olhar o que fui na fotografia não... não voltarei a suicidar-me

pelo menos esta noite estou longe de desejar a eternidade. ${ }^{49}$
Não é em vão que Al Berto escolheu a fotografia como um de seus assuntos, bem como para ser estampada em seus livros. O fascínio por essa arte se desdobra e agrega temas complexos, como a reflexão sobre a memória e a própria escrita e o estatuto do eu e sua posição no mundo, como explícito em seu escrito diarístico "O medo (1)":

com fotografias consolo a saudade do rapaz que fui, embora saiba que há muito se apagaram os sorrisos de teu rosto. envelhecemos separados, o eu das fotografias e o eu daquele que neste momento escreve. envelhecemos irremediavelmente, tenho pena, mas é tarde e estou cansado para as alegrias dum reencontro. não acredito na reconciliação. ainda menos no regresso ao sorriso que tenho nas fotografias. não estou aqui. nunca estive nelas. quase nada sei de mim. ${ }^{50}$

Essa disposição está em estreita relação com o que Barthes nos propõe a pensar sobre o assunto:

Eu queria, em suma, que minha imagem, móbil, sacudida entre mil fotos variáveis, ao sabor das situações, das idades, coincidisse sempre com meu "eu" (...); mas é o contrário que é preciso dizer: sou "eu" que não coincido jamais com minha imagem; pois é a imagem que é pesada, imóvel, obstinada (por isso a sociedade se apoia nela), e sou "eu" que sou leve, dividido, disperso e que, como um ludião, não fico no lugar, agitan- 
51. BARTHES. $A$ câmara clara, p. 24.

\section{MEDEIROS. Fotografia e} narcisismo, p. 55.

53. BARTHES. $A$ câmara clara, p. 27.

54. BARTHES. A câmara clara, p. 22. do-me em meu frasco: ah, se ao menos a Fotografia pudesse me dar um corpo neutro, anatômico, um corpo que nada signifique! Infelizmente, estou condenado pela Fotografia, que pensa agir bem, a ter sempre uma cara: meu corpo jamais encontra seu grau zero, ninguém o dá a ele. ${ }^{5}$

Ressalte-se que, de maneira geral, segundo Margarida Medeiros, a fotografia é "pseudo-real, pseudo-especular, mas ainda assim real e especular, [pois] vai permitir ao sujeito jogar um novo jogo: o da inclusão mágica, de si mesmo, no olhar do Outro". ${ }^{52}$

Para Barthes, o retrato está sempre inserido num tecido cultural, havendo, nesse campo de forças, possibilidades de leitura conforme a época. Por conseguinte, quatro imaginários se entrecruzam nesse jogo: "aquele que eu me julgo, aquele que gostaria que me julgassem, aquele que o fotógrafo me julga e aquele de que ele se serve para exibir sua arte". ${ }^{53}$ Daí advém o espaço para se pensar na pose da encenação para o retrato: "a partir do momento que me sinto olhado pela objetiva, tudo muda: ponho-me a 'posar', fabrico-me instantaneamente um outro corpo, metamorfoseio-me antecipadamente em imagem. Essa transformação é ativa: sinto que a Fotografia cria meu corpo ou mortifica-o, a seu bel-prazer" ${ }^{54}$ A pose está incluída, ao lado dos objetos colocados em cena, da trucagem, da fotogenia, do esteticismo e da sintaxe, como "procedimentos de conotação" da fotografia,

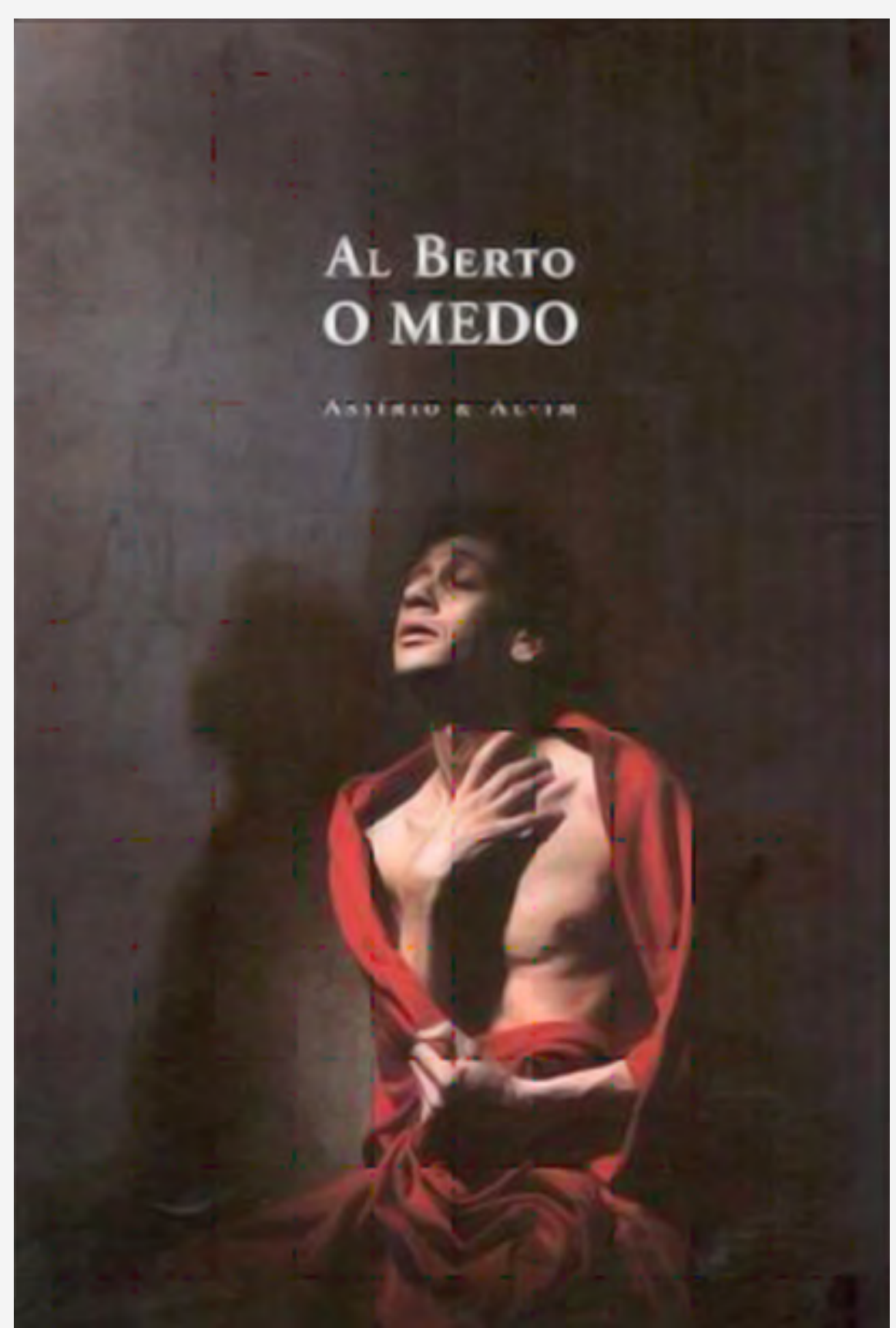


55. BARTHES. A mensagem fotográfica, p. 16.

56. BARTHES. A mensagem fotográfica, p. 17.

57. A fotografia de Al Berto desaparece nas reedições de O medo de 1997 e 2000 . O livro é editado apenas com as referências básicas para a distinção da obra - título, autor e editora. A capa é negra, com as lombadas arroxeadas, em alusão à morte recente do autor. aspecto que Barthes desenvolve no ensaio "A mensagem fotográfica”, do livro O óbvio e o obtuso. Sobre os três primeiros procedimentos referidos, Barthes diz não serem específicos dessa arte, visto que: "a conotação é produzida por uma modificação do próprio real, isto é, da mensagem denotada (...); se o incluímos, porém, nos procedimentos de conotação fotográfica, é porque também se beneficiam do prestígio da denotação". ${ }^{55} \mathrm{Ou}$ seja, esses procedimentos conotativos agregam sentido à mensagem fotográfica e estão sempre subjugados à leitura de uma determinada cultura, isto é, sob a interferência de certos valores.

Vejam-se apenas os procedimentos encontrados em AlBerto: a pose e o objeto. O primeiro resulta de um efeito do fato que "o leitor recebe como uma simples denotação o que é, na verdade, uma estrutura dupla, denotada-conotada" ${ }^{56} \mathrm{O}$ poeta-performer utilizava esse artifício em todas as suas fotografias. Seu retrato mais conhecido e difundido pela imprensa encontra-se na capa da obra reunida $O$ medo (1987), fotografada por Nozolino. ${ }^{57}$ A encenação é uma referência a Michelangelo Caravaggio (15711610), pintor considerado enigmático, fascinante e perigoso adjetivos encontrados igualmente no retrato al-bertiano. Ao examinar essa fotografia, infere-se certa intenção do bardo de dialogar com a época caravaggiana, atribuindo, dessa forma, uma justaposição temporal, trazendo mais elementos para sua análise, pois a imagem refere-se simultaneamente aos períodos medieval e barroco. Com relação à Idade Medieval, podemos destacar a alusão da imagem aos retratos pictóricos do fim dessa época - prática habitual -, devido à proximidade de Caravaggio a esse período e à afecção dos monges em seus claustros tomados pelo flagelo acidioso, representados pelas cores negra, ao fundo, e vermelho-sangue, do manto, além da sombra - o espectro humano - do poeta projetada numa parede. É essa imagem que primeiramente me punge ao mirar essa fotografia, pois a partir dela é refletida a possibilidade de articulação da teoria aristotélica do fantasma, apontada por Giorgio Agamben,

com a pneumatologia estoico-médico-neoplatônica, em que uma experiência que é, ao mesmo tempo e na mesma medida, "movimento espiritual" e processo fantasmático. Só esta complexa herança cultural pode explicar a característica dimensão, contemporaneamente real e irreal, fisiológica e soteriológica, objetiva e subjetiva, que a experiência erótica tem na lírica estilo-novista. O objeto do amor é, com efeito, um fantasma, mas tal fantasma é um "espírito", inserido, como tal, em um círculo pneumático no qual ficam abolidas e confundidas as fronteiras entre o exterior e o interior, o corpóreo e incorpóreo, o desejo e o seu objeto. ${ }^{58}$

Vale a pena também lembrar que esse período foi glorioso para a poesia galaico-portuguesa (período trovadoresco), a qual, em sua grande parte, cantava a ausência do amor. O torso nu traz uma leve erotização à imagem, acrescida à
58. AGAMBEN. Estâncias, p. 182. Cf. AGAMBEN. A palavra e o fantasma - a teoria do fantasma na poesia de amor do século XIII. Estâncias, p. 119-214.
EM TESE
BELO HORIZONTE
v. 21
N. 2
MAIO-AG0. 2015
GUIMARÃES. Fotografia e melancolia: Al Berto (e Barthes)
P. $90-112$ 
59. BARTHES. A câmara clara, p. 27. pose dual entre o êxtase e a aflição expressa em seu rosto, além das mãos teatralmente dispostas: uma lânguida sobre o pescoço, levemente erotizada, sugerindo um movimento ascendente e, a outra, tensionada, comprimindo-se para baixo (para despir o manto?). Dessa forma, retomando Barthes, a fotografia representa o "momento muito sutil em que, para dizer a verdade, não sou nem um sujeito nem um objeto, mas antes um sujeito que se sente tornar-se objeto: vivo então uma microexperiência da morte (do parêntese): torno-me verdadeiramente espectro" ${ }^{59}$ Nesta altura, essa referida dualidade também aponta elementos para uma breve aproximação ao Barroco - época à qual o pintor Caravaggio é normalmente identificado, destacando-se como o primeiro grande representante desse estilo -, tendo em vista que, além do certo caráter religioso sugerido pela fotografia, percebe-se, em especial, a evidência da contradição - prazer e dor, forte e fraco, infernal e divino, espiritual e material traços característicos desse período.

O segundo procedimento de conotação referido por Barthes, o objeto, são propriamente os objetos encontrados na cena, capturados pela objetiva. É certo que a pose predomina em Al Berto, pois é o que, geralmente, mais chama a atenção em suas fotos, sobretudo a expressão facial. Porém, numa segunda instância, percebem-se os objetos dispostos teatralmente na última imagem a analisar, na qual se vê o cigarro mais uma vez à mão e as asas do homem alado. Barthes novamente nos ajuda a pensar acerca dos objetos em cena:

o interesse está no fato de que esses objetos são indutores comuns de associações de ideias (biblioteca $=$ intelectual) ou, de maneira menos evidente, verdadeiros símbolos (a porta da câmara de gás de Chessmann remete à porta fúnebre das antigas mitologias). Esses objetos constituem excelentes elementos de significação: por um lado, são descontínuos e completos em si mesmos, o que, para um signo, é uma qualidade física; e, por outro lado, remetem a significantes claros, conhecidos; são, pois, elementos de um verdadeiro léxico, estáveis a ponto de se poder facilmente estabelecer sua sintaxe. (...) O objeto talvez não possua mais uma força, mas possui, certamente, um sentido. ${ }^{60}$

Nesta fotografia na capa de O anjo mudo, de Adriana Freire, Al Berto está posando para uma cena fake; em uma idade já madura, o poeta usa pequenas asas postiças (não esconde-se a alça à altura dos ombros), segurando um cigarro entre os dedos próximos ao peito, e, mais uma vez, a sombra - espectro - aparece projetada na parede ao fundo da imagem. O retrato é em preto e branco, trazendo nuanças entre claro e escuro, contrastes entre luz e sombra, caracterizando juntamente com o olhar sóbrio e levemente interrogativo - levando em
60. BARTHES. A mensagem fotográfica, p. 17-18. 


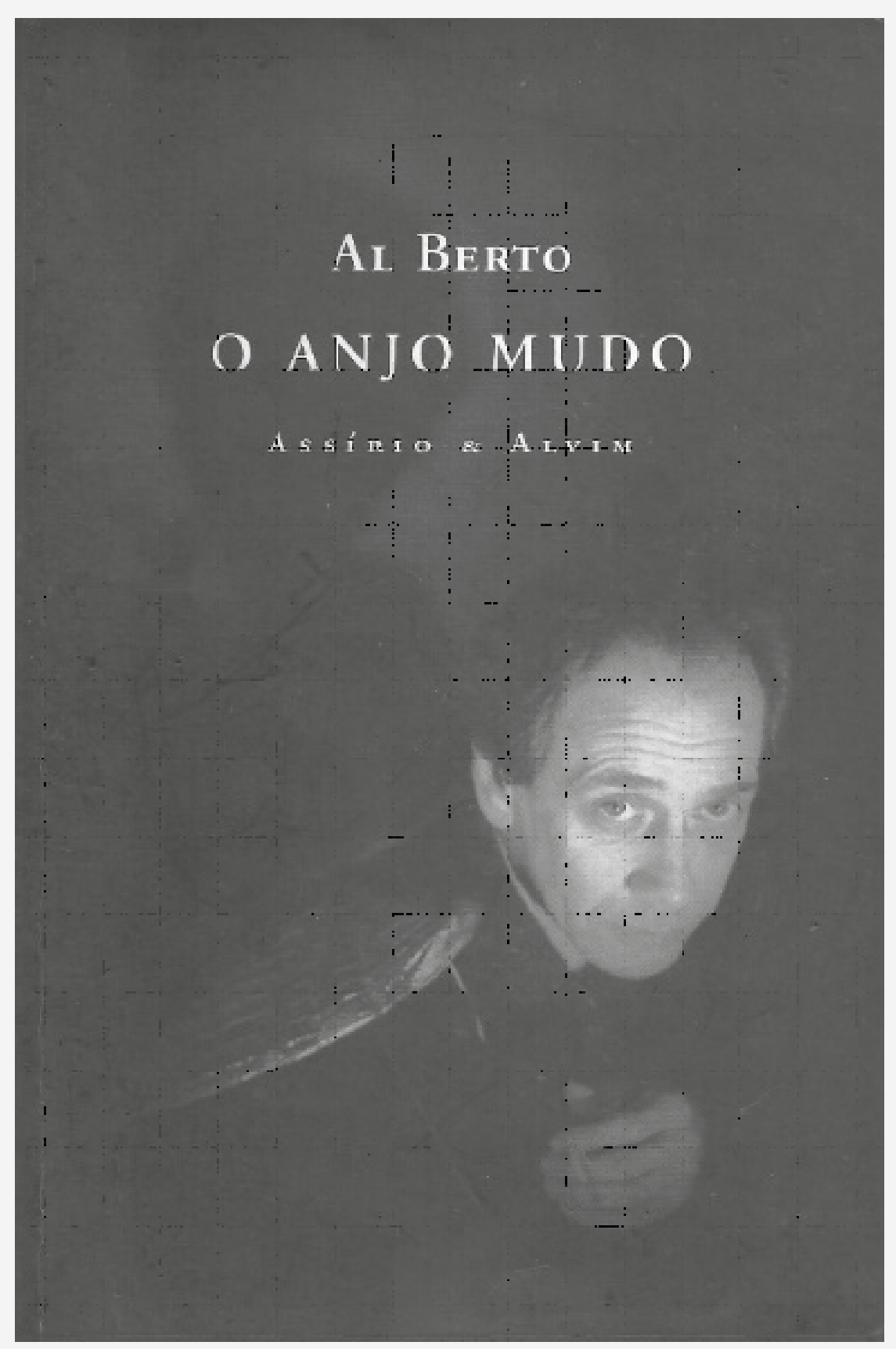

consideração o franzido da testa - uma oscilação entre posições contraditórias, típicas da disposição melancólica. Além, é claro, de o próprio anjo ser uma figura paradoxal - lembre-se de Satanás, anjo mau e rebelde. Esse indício fica ainda mais caracterizado quando pensamos que a imagem traz um tom de provocação à moralidade religiosa, através dos objetos em diálogo colocados diante da objetiva: o par de asas fake e o cigarro arranjados em uma mesma linha - o profano e o sagrado, a terra e o céu, o vício e a virtude. Vista por esse ângulo, a cena torna-se demasiadamente irônica.

Nesse jogo especular, as questões pertinentes à identidade/ alteridade, familiar/estranho, sujeito/objeto, real/imaginário, desdobram-se em consonantes e complexas estratégias do autor para se autorretratar, suscitam discussões acerca da autoria e da função do autor nos dias atuais, questões muito caras também a Roland Barthes. Em Al Berto, há maior valorização da fonte factual ou documental - a exemplo das fotografias -, com o intuito de tensionar os limites entre vida e obra, há nele a inclinação de estetização de sua própria vida, a exemplo do que propõe Gilles Deleuze, no ensaio "A literatura e a vida": "escrever não é contar as próprias lembranças, suas viagens, seus amores e lutos, sonhos e fantasmas. Pecar por excesso de realidade ou de imaginação é a mesma coisa. (...) A literatura segue a via inversa, e só se instala descobrindo sob as aparentes pessoas a potência de um impessoal”. ${ }^{61}$

61. DELEUZE Crítica e clínica, p. 12-13. 
Assim, este estudo reclama a importância das artes fotográficas como paratexto na obra al-bertiana, pois é curioso constatar que elas foram alijadas da obra completa do autor nas sucessivas edições de $O$ medo. Essa aproximação em A Berto nos fornece estudos ainda mais promissores. Para finalizar, ratifica-se que as fotografias estão, sem dúvida, entre os fatores que ajudam a compreender a obra al-bertiana sobretudo ao lado da abordagem aqui proposta, em contato com a melancolia e com os textos barthesianos. Acrescentase um trecho da belíssima narrativa "O esconderijo do homem triste”, presente na terceira parte de $O$ anjo mudo, na qual a voz que se enuncia refere-se ao processo de revelação fotográfica, fundindo-se a ele. Mostra-se, também, o lugar onde o sujeito se esconde e demonstra o desejo de se tornar Todo-Imagem - ou Eu-Fotografia:

Fui ter com um fotógrafo meu amigo e pedi-lhe para me retratar. Ele acendeu um foco de luz. Sentei-me no centro dele. A máquina disparou sem cessar.

Gesticulei, abri os braços, mexi-me muito - como se soubesse que nunca mais o voltaria a fazer.

Quando o meu amigo mergulhou o papel fotográfico no revelador, eu também mergulhei. Mas devo ter desmaiado un segundos, talvez minutos, porque ao retomar consciência senti as pernas e os braços dormentes - e todo o meu corpo estava mole.
Um véu de luz toldou-me a visão. Ceguei por instantes, mas não foi uma sensação desagradável. Depois, o corpo começou a ondear, a impregnar-se no papel e a coincidir com o retrato que o meu amigo fizera de mim.

Segundos mais tarde uma pinça - e toda a superfície da folha de papel, o meu novo corpo, brilhou. Em seguida deixei-me entorpecer na temperatura tépida, voluptuosa do fixador.

Tinha encontrado meu esconderijo. ${ }^{62}$

62. AL BERTO. $O$ anjo mudo, p. $75-76$.

\section{REFERÊNCIAS}

AGAMBEN, Giorgio. Estâncias: a palavra e o fantasma na cultura ocidental. Trad. Selvino José Assmann. Belo Horizonte: Ed. UFMG, 2007

AL BERTO. Projectos 69. Lisboa: Assírio \& Alvim, 2002 [1972].

AL BERTO. À procura do vento num jardim d'agosto

(fragmentos dum exílio) 1974-75. Lisboa: Alberto R. Pidwell Tavares, Editor, col. Subúrbios n. 2, 1977. (Capa de Alberto R. Pidwell Tavares).

AL BERTO. Lunário. Lisboa: Contexto, 1988. Capa: fotografia do autor s/ autoria. $2^{a}$ ed. Lisboa: Assírio \& Alvim, 1999. (Capa: fotografia do autor s/ autoria).

AL BERTO. O anjo mudo. Lisboa: Contexto, 1993. (Capa e contracapa: fotografias de Al Berto por Luísa Ferreira). $2^{\mathrm{a}}$ ed. Assírio \& Alvim, 2000. (Fotografia do autor por Adriana Freire). 
AL BERTO. Horto de incêndio. $3^{a}$ ed. Lisboa: Assírio \& Alvim, 2000 [1997]. (Capa: Al Berto, Lisboa, 1990, fotografia de Paulo Nozolino).

AL BERTO. O medo - trabalho poético 1974-1997. $3^{\mathrm{a}}$ ed., revista e aumentada. Lisboa: Assírio \& Alvim, 2005; 4ª ed., 2009 (Capa dura: fotografia do autor em homenagem a Caravaggio por Paulo Nozolino)

AMARAL, Fernando Pinto do. Al Berto: um lirismo do excesso e da melancolia. In

0 mosaico fluido. Lisboa: Assírio \& Alvim 1991, p. 119-30.

ALCIDES, Sérgio. Sob o signo da iconologia: uma exploração do livro Saturno e a melancolia, de R. Klibansky, E. Panofsky e Saxl. Topoi - Revista de História. Rio de Janeiro: Programa de Pós-graduação em História Social da UFRJ, v. 2, jul/dez, 2001; p. $131-73$

ANGHEL, Golgona Luminita. A Metafísica do Medo: leituras da obra de Al Berto. Tese (Doutorado em Literatura Portuguesa Contemporânea). Faculdade de Letras de Lisboa, Lisboa, 2008. Disponível em http://repositorio.ul.pt/handle/10451/542. Acess em 25 set. 2012

ANGHEL, Golgona Luminita. Eis-me acordado muito tempo depois de mim: uma biografia de Al Berto. Vila Nova de Famalicão: Quase Edições, 2006.

ARISTÓTELES. O homem de gênio e a melancolia: o problema XXX, i. Tradução do grego, apresentação e notas de Jackie Pigeaud; tradução de Alexei Bueno. Rio de Janeiro: Lacerda Editores, 1998, p. 81-128.
BARRENTO, João. O astro baço - a poesia portuguesa sob o signo de Saturno. In: A palavra transversal: literatura e ideias no século xx. Lisboa: Cotovia, 1996, p. 79-94.

BARTHES, Roland. Roland Barthes por Roland Barthes. Trad Leyla Perrone-Moisés. São Paulo: Cultrix, s/d [1975].

BARTHES, Roland. A câmara clara: nota sobre a fotografia. Trad. Júlio Castañon Guimarães. Rio de Janeiro: Nova Fronteira, 1984 [1980].

BARTHES, Roland. A mensagem fotográfica. In:

O óbvio e o

obtuso. Trad. Léa Novaes. Rio de Janeiro: Nova Fronteira, 1990 [1982]

BENJAMIN, Walter. 3. In

Origem do drama trágico alemão Trad. João Barrento. Lisboa: Assírio \& Alvim, 2004, p. 145-69.

CASTRO, Maria David Neves Dias de. Autorretrato e construção da subjetividade na poesia de Al Berto. Dissertação (Mestrado em Literaturas Românicas). Faculdade de Letras do Porto, Porto, 2005.

COELHO, Eduardo Prado. Pensar a ausência em Al Berto. In VÁRIOS. Al Quimias: Al Berto - as imagens como desejo de poesia. Sines: Centro Cultural Emmerico Nunes, 2001, p. 12-13.

FREITAS, Manuel de. Me, Myself and I: autobiografia e imobilidade na poesia de Al Berto. Lisboa: Assírio \& Alvim, 2005

FREUD, Sigmund. Sobre o narcisismo: uma introdução (1914); Luto e melancolia (1917 [1915]). In: _. Edição Standart Brasileira das Obras Psicológicas Completas de Sigmund Freud vol XIV (1914-1916). Trad. Jayme Salomão. Rio de Janeiro: Imago, 1974, p. 81-119; p. 271-91. 
GUIMARÃES, Gustavo Cerqueira. Al Berto, um corpo incendiado.

In: FORNACIARI, Christina (org.). Corpo em contexto. Belo

Horizonte: Scriptum, 2014, p. 64-77.

GUIMARÃES, Gustavo Cerqueira. Al Berto, poeta editor: as

margens da poesia. Estudos Linguísticos e Literários, revista

do Programa de pós-graduação do Instituto de Letras da

Universidade Federal da Bahia, 2015, n 51, p. 1-18. Disponível

em: http://www. portalseer.ufba.br/index.php/estudos/article/

view/13745/9642. Acesso 03 set. 2015.

LAGES, Susana Kampff. Walter Benjamin: tradução e

melancolia. São Paulo: Edusp, 2007.

MEDEIROS, Margarida. Fotografia e narcisismo: o autorretrato

contemporâneo. Lisboa: Assirio \& Alvim, 2000.

SONTAG, Susan. Sobre fotografia. Trad. Rubens Figueiredo. São Paulo: Cia das Letras, 2004 